\title{
MINAT BACA DAN GAYA BELAJAR MAHASISWA LPTK SEBAGAI CALON GURU PROFESIONAL DI ERA DIGITAL
}

\author{
${ }^{1}$ Lussy Dwiutami Wahyuni, \\ ${ }^{2}$ Winda Dewi Listyasari \& ${ }^{3}$ Anna Armeini Rangkuti \\ e-mail: lussysf@unj.ac.id \\ Kampus D Universitas Negeri Jakarta
}

Jalan Halimun No. 2 Jakarta Selatan

\begin{abstract}
Abstrak: Tujuan dari penelitian ini adalah untuk menguji apakah ada hubungan yang signifikan antara minat membaca dan gaya belajar siswa LPTK sebagai calon guru profesional. Jumlah sampel yang diambil yaitu 126 sampel yang diambil dari 4 LPTK yang sebelumnya adalah sebuah perguruan tinggi Guru Besar Negeri (IKIP Negeri) pada bulan Juni - November 2016, yang melibatkan 126 responden. Data dianalisis dengan menggunakan aplikasi bantuan Statistical Product and Service Solutions (SPSS) versi 21 dan Winstep versi 37.1 aplikasi pemodelan Rasch untuk mengetahui kategori responden yang lebih tidak pasti. Hipotesis diuji dengan menggunakan metode korelasi nonparametrik Cramer's $V$. Hasil penelitian menunjukkan bahwa perkiraan secara signifikan. $(0,818)$ lebih tinggi dari alfa $(0,05)$, dapat disimpulkan bahwa Hipotesis Null (H0) "tidak ada hubungan yang signifikan antara minat membaca dan gaya belajar pada siswa LPTK".
\end{abstract}

Kata kunci: minat baca, gaya belajar, mahasiswa LPTK.

\section{READING INTEREST AND LEARNING STYLES OF LPTK STUDENTS AS A PROFESSIONAL TEACHER CANDIDATE IN THE DIGITAL ERA}

Abstract: The purpose of conducting this research was to examine whether there is significant correlation or not between reading interest and learning style of LPTK's students as professional teacher candidates. 126 samples were taken from 4 LPTK was previously a state Teachers' Training College (IKIP Negeri) in June-November 2016, involving 126 respondents. Data were analyzed using an application aid Statistical Product and Service Solutions (SPSS) version 21 and Winstep version 37.1 applications Rasch modeling to determine the categories of respondents are more uncertain. Hypotheses were tested using Cramer's V nonparametric correlation method. The Result showed that approximate significantly. (0.818) was higher that alpha (0.05), it can be concluded that the Null Hypothesis (H0) "there is no significant correlation between reading interest and learning style on LPTK's students".

Keywords : reading interest, learning styles, LPTK's student.

\section{PENDAHULUAN}

Lembaga Pendidikan dan Tenaga Kependidikan (LPTK) adalah institusi yang diberi mandat oleh pemerintah untuk mencetak calon-calon guru. Dalam UU No. 14 tentang Guru dan Dosen pasal 12 tertera bahwa "Setiap orang yang memiliki sertifikat pendidik, memiliki kesempatan untuk diangkat menjadi guru pada satuan pendidikan tertentu." Dengan kata lain, secara legal profesi guru sudah menjadi profesi terbuka. Inipun akhirnya berimplikasi pada LPTK sebagai lembaga pencetak tenaga pendidik profesional yang mempunyai tugas pokok menyelenggarakan pendidikan bagi calon tenaga kependidikan untuk semua jenjang kependidikan serta keahliannya.

Menurut Dirjen Dikti Kemendikbud, Joko
Susilo, jumlah LPTK per April 2013 ada sebanyak 415 LPTK yang terdiri dari 376 LPTK swasta, 26 FKIP negeri, satu FKIP Universitas Terbuka, dan 12 eks IKIP negeri. Lebih lanjut Joko Susilo mengatakan bahwa $60 \%$ mutu LPTK rendah. Selain itu LPTK masih belum mampu dalam mempersiapkan mahasiswa calon guru yang profesional (Juangsih, 2015). Banyak faktor yang mempengaruhi hal tersebut, diantaranya: budaya akademik yang dibangun LPTK, kualitas dosen, kurikulum, metode pembelajaran, dan kualitas mahasiswa.

Saat berbicara mengenai cara meningkatkan kualitas mahasiswa, maka secara tidak langsung akan terkait dengan budaya akademik yang dibangun LPTK, kualitas dosen, kurikulum, dan juga metode pembelajaran. Dikatakan demikian, karena ketiga hal tersebutlah yang nantinya akan mentransformasi 
mahasiswa (sebagai input) menjadi calon-calon guru yang berkarakter dan berkualitas.

Salah satu budaya akademik yang harus dikembangkan oleh LPTK adalah budaya membaca. Dengan membaca, maka akan banyak pengetahuan yang dapat diketahui. Semakin banyak hal yang diketahui, maka akan semakin memperluas wawasan dan selanjutnya diharapkan akan semakin bijaksana dalam pengambilan keputusan. Hal tersebut harus dimiliki oleh seorang guru profesional, dimana salah satu fungsi guru adalah mentransformasi pengetahuan baru ke peserta didiknya dan juga pendidik.

Namun sayangnya, dari penelitian yang dilakukan oleh Deni Hardianto tentang minat baca mahasiswa Fakultas Ilmu Pendidikan UNY, salah satu hasilnya menyatakan bahwa intensitas waktu yang diluangkan mahasiswa dalam membaca buku relatif rendah, yaitu kurang dari 1 jam tiap harinya bahkan ada yang tidak pernah sama sekali meluangkan waktu untuk membaca, kecuali menjelang ujian (Hardianto, 2011). Fenomena tersebut sedikit banyaknya dipengaruhi oleh budaya membaca keluarga/masyarakat Indonesia yang masih rendah. Badan Pusat Statistik pun pada tahun 2006 pernah mempublikasikan bahwa masyarakat Indonesia belum menjadikan membaca sebagai kegiatan untuk mendapatkan informasi. Mereka lebih memilih menonton televisi $(85,9 \%)$ dan mendengarkan radio $(40,3 \%)$, daripada membaca (23,5\%) (Siswati, 2010). Ternyata setelah 10 tahun kemudian fenomena itu pun masih belum berubah. Dari survei yang dilakukan oleh Central Connecticut State University sejak 2003 hingga 2014 di New Britain yang bekerja sama dengan sejumlah peneliti sosial menyatakan Indonesia berada di peringkat 60 dari 61 negara terkait minat baca. Indonesia hanya unggul dari Bostwana di posisi 61, sedangkan Thailand berada di posisi 59 (Ferdianto, 2016).

Hasil penelitian tersebut tidak menjabarkan secara detil apa yang membuat Indonesia berada di peringkat tersebut, apakah memang karena tidak memiliki kemampuan membaca atau memang karena tidak termotivasi untuk membaca. Hal ini senafas dengan yang dikemukan Mikulecky (1978, dalam Siswati, 2010), bahwa ada dua karakteristik individu terkait aktivitas membaca, yaitu: (1) aliterasi adalah individu yang tidak memiliki motivasi intrinsik untuk membaca, padahal mereka mampu memahami bacaan dengan baik; dan (2) iliterasi adalah individu yang benar-benar tidak mampu membaca. Menurut Decker (1986, dalam Siswati, 2010) ada tiga penyebab utama aliterasi pada peserta didik, yaitu: (1) rendahnya perkembangan kosa kata dan pengajaran yang kurang memadai; (2) meningkatnya kebiasaan menonton TV; dan (3) tes dan ujian sekolah yang memaksa pengajar memberikan bahan bacaan yang harus diajarkan dan disertai dengan latihan terus menerus sehingga menghilangkan kesenangan untuk membaca. Selain itu dengan adanya infiltrasi era digital, membuat informasi menjadi tampil dengan dinamis dan menarik. Implikasinya, individu yang biasa berselancar di internet akan mudah merasa bosan dan enggan kala berhadapan dengan buku teks yang cenderung berpenampilan monoton.

Untuk hal tersebut, seorang ilmuwan Jerman, Gunther Kress (1997, dalam Pendit 2013), telah mengingatkan tentang adanya empat perubahan penting dalam kegiatan dan kebiasaan membaca, yaitu: (1) the shift from page to screen - munculnya kebiasaan membaca di atas layar; (2) the shift from text as an ordered word to text as a set of resources - teks bukan lagi semata-mata rangkaian kata yang teratur, tetapi juga sumber daya untuk berpindah-pindah makna, untuk perilaku copy and paste, dan untuk dikutip atau dirujuk; (3) the shift from the ordered path to the unordered arrangement of the hypertext - kegiatan membaca tak lagi harus runut dan linear (garis lurus), tetapi dapat melompat-lompat dari satu teks ke teks lainnya; dan (4) a shift from reading to use - membaca bukan lagi sekadar untuk membaca, melainkan untuk menggunakan bacaan itu dalam berbagai aktivitas.

Untuk mengatasi hal tersebut, maka para pengajar harus benar-benar memahami peserta didiknya, sehingga metode pembelajaran yang akan diberikan akan efektif dan efisien. Salah satu cara agar dapat memberikan metode pembelajaran yang efektif dan efisien adalah dengan mengetahui gaya belajar dari setiap peserta didiknya.

Menurut Pashler, McDaniel, Rohrer, and Bjork (2009), Gaya belajar adalah "The concept that individuals differ in regard to what mode of instruction or study is most effective for them". Konsep ini secara eksplisit menyatakan bahwa jika pembelajaran ingin efektif, maka seorang pengajar harus memahami gaya belajar setiap peserta didiknya. Hal ini dikarenakan gaya belajar adalah cara-cara yang biasa dimiliki seseorang dalam memahami informasi yang diperolehnya.

Flemming (dalam VARK Learning) menyatakan bahwa ada 4 gaya belajar, yaitu: (1) visual, orang dengan gaya belajar ini butuh melihat bahasa tubuh dan ekspresi wajah sang pengajar untuk dapat memahami konten pembelajaran secara utuh. Pada 
umumnya mereka lebih memilih untuk duduk di depan kelas. Orang dengan gaya belajar ini berpikir dalam gambar dan dapat belajar dengan tampilan visual, seperti: diagram, buku pelajaran bergambar, OHT, video, flipchart, papan tulis interaktif, dan handout. Selama pelajaran atau diskusi, orang visual biasanya lebih memilih mengambil catatan rinci untuk menyerap informasi; (2) auditory, orang dengan gaya belajar ini lebih baik belajar melalui verbal, diskusi, dialog, dan mendengarkan apa yang dikatakan orang lain. Auditori menafsirkan makna pembicaraan melalui mendengarkan nada suara, intonasi, dan kecepatannya. Orang dengan gaya ini lebih banyak mendapatkan manfaat kala membaca catatannya dengan keras atau mendengarkan rekaman suara dan juga informasi berupa teks; (3) membaca/menulis, orang dengan gaya belajar ini lebih menyukai informasi dalam bentuk kata. Selain itu, mereka juga menyukai bekerja dengan menggunakan power point, internet, catatan, kamus, dan kata-kata; (4) kinestetik, orang dengan gaya belajar ini lebih baik menggunakan pendekatan dengan praktek langsung. Terkadang, orang dengan gaya ini agak sulit untuk duduk dalam waktu yang lama. Mereka pun jadi terganggu akan kebutuhannya untuk bergerak tersebut.

Beranjak dari masalah yang ada, maka pada akhirnya ditelitilah tentang hubungan minat baca dengan gaya belajar mahasiswa LPTK sebagai calon guru profesional di era digital.

\section{METODE PENELITIAN}

Penelitian ini meggunakan pendekatan kuantitatif deskriptif, yaitu "suatu rumusan masalah yang berkenaan dengan pertanyaan terhadap keberadaan variabel mandiri, baik hanya pada satu variabel atau lebih" (Sugiyono, 2007). Penelitian ini dilaksanakan di 4 LPTK, yaitu: Universitas Negeri Jakarta di wilayah DKI Jakarta, Universitas Pendidikan Indonesia di wilayah Bandung Jawa Barat, dan Universitas Negeri Semarang di wilayah Semarang pada bulan Juni - November 2016. Subjek dipilih dengan menggunakan teknik purposive sampling, yaitu sampel diambil berdasarkan tujuan tertentu (Asra \& Prasetyo, 2015).

Data dikumpulkan dengan menggunakan instrumen kuesioner yaitu alat untuk mengumpulkan data yang berupa daftar pertanyaan yang disampaikan kepada responden untuk dijawab secara tertulis (Riyanto, 2001) dan juga skala, yaitu alat/instrumen yang digunakan untuk mengukur aspek/atribut afektif (Azwar, 2010). Kemudian, data yang diperoleh dianalisis dengan menggunakan bantuan aplikasi Statistical Product and Service Solutions (SPSS) versi 21 dan aplikasi Winstep versi 37.1 untuk pemodelan Raschnya. Hipotesis yang diajukan adalah terdapat hubungan antara gaya belajar dengan minat membaca pada mahasiswa LPTK.

\section{HASIL DAN PEMBAHASAN}

\section{Hasil}

Data yang berhasil dikumpulkan berasal dari 163 responden. Namun dikarenakan 37 responden tidak menjawab pertanyaan secara lengkap, maka dengan demikian data responden tersebut dinyatakan mortal (tidak diikutsertakan dalam analisis), sehingga data yang dianalisis hanya 126 responden. Data demografis responden ditinjau dari segi jenis kelamin, angkatan, usia, asal universitas, dan program studi. Dari segi jenis kelamin, responden terdiri dari 89 perempuan (70.6\%) dan 37 laki-laki (29.4\%). Dengan sebaran usia 3 responden (2.4\%) berusia 19 tahun, 37 responden $(29.4 \%)$ berusia 20 tahun, 51 responden $(40.5 \%)$ berusia 21 tahun, 30 responden $(23.8 \%)$ berusia 22 tahun, dan 5 responden $(4.0 \%)$ berusia 23 tahun. Bila dilihat dari angkatannya, maka sebanyak 5 responden $(4.0 \%)$ berasal dari angkatan 2011, 49 responden $(38.9 \%)$ berasal dari angkatan 2012, 30 responden (23.8\%) berasal dari angkatan 2013, dan 42 responden (33.3\%) berasal dari angkatan 2014.

Tabel 1. Hasil Penelitian Variabel Gaya Belajar

\begin{tabular}{lcc}
\hline \multicolumn{1}{c}{ Kategorisasi } & Frekuensi & Persentase \\
\hline Visual (V) & 81 & 64.3 \\
Auditori (A) & 17 & 13.5 \\
Kinestetik (K) & 18 & 14.3 \\
Visual Audio (VA) & 3 & 2.4 \\
Visual Kinestetik (VK) & 5 & 4.0 \\
Audio Kinestetik (AK) & 2 & 1.6 \\
\hline \multicolumn{1}{c}{ Total } & 126 & 100 \\
\hline
\end{tabular}

Berdasarkan tabel 1 dapat diketahui bahwa subjek paling banyak memiliki gaya belajar visual, yaitu sejumlah 81 orang $(64.3 \%)$ dan paling sedikit memiliki gaya belajar perpaduan antara audio dengan kinestetik, yaitu sejumlah 2 orang (1.6\%).

Tabel 2. Hasil Penelitian Variabel Minat Baca

\begin{tabular}{lccc}
\hline Kategorisasi & Skor & Frekuensi & Persentase \\
\hline Rendah & $X<0.5$ logit & 71 & 56.34 \\
Sedang & 0.5 logit $\leq x \leq 1.52$ logit & 51 & 40.48 \\
\hline
\end{tabular}




\begin{tabular}{|c|c|c|c|}
\hline Kategorisasi & Skor & Frekuensi & Persentase \\
\hline Tinggi & $X>1.52$ logit & 4 & 3.17 \\
\hline \multicolumn{2}{|r|}{ Total } & 126 & 100 \\
\hline
\end{tabular}

Berdasarkan tabel 2 dapat diketahui bahwa subjek paling banyak memiliki minat baca sedang, yaitu sejumlah 90 orang $(70.3 \%)$ dan paling sedikit memiliki minat baca rendah, yaitu sejumlah 18 orang $(14.06 \%)$.

Tabel 3. Crosstab Hasil Penelitian Variabel Gaya Belajar dengan Minat Baca

\begin{tabular}{lcccc}
\hline \multirow{2}{*}{ Gaya Belajar } & \multicolumn{3}{c}{ Minat Baca } & \multirow{2}{*}{ Total } \\
\cline { 2 - 4 } & Rendah & Sedang & Tinggi & \\
\hline Visual (V) & 43 & 35 & 3 & 81 \\
Auditori (A) & 8 & 8 & 1 & 17 \\
Kinestetik (K) & 12 & 6 & 0 & 18 \\
Visual Audio (VA) & 3 & 0 & 0 & 3 \\
Visual Kinestetik (VK) & 4 & 1 & 0 & 5 \\
Audio Kinestetik (AK) & 1 & 1 & 0 & 2 \\
\hline \multicolumn{1}{c}{ Total } & $\mathbf{7 1}$ & $\mathbf{5 1}$ & $\mathbf{4}$ & $\mathbf{1 2 6}$ \\
\hline
\end{tabular}

Dikarenakan data bertipe nominal, maka hipotesis diuji dengan menggunakan uji nonparametrik. Seperti halnya yang dikatakan Santoso (2015), ada 3 hal yang menyebabkan suatu data harus diuji dengan metode nonparametrik diantaranya data tidak berdistribusi normal atau varians tidak sama, jumlah data terlalu sedikit (kurang dari 30), dan data bertipe nominal atau ordinal. Salah satu metode nonparametrik untuk menguji hubungan adalah dengan menggunakan Korelasi Cramer. Dari hasil pengujian hipotesisnya diperoleh hasil signifikansi $\mathrm{p}$ sebesar 0.818 , atau lebih besar dari nilai siginifikansi a (0.05). Dengan demikian dapat dikatakan hipotesis tidak teruji atau $\mathrm{H} 0$ gagal ditolak artinya tidak terdapat hubungan antara gaya belajar dengan minat baca pada mahasiswa LPTK. Hasil pengujian hipotesis secara jelas dapat dilihat pada tabel 4 .

Tabel 4. Hasil Uji Hipotesis Variabel Gaya Belajar dengan Minat Baca

\begin{tabular}{lcc}
\hline & Value & Approx. Sig. \\
\hline Cramer's V & 0.154 & 0.818 \\
Contigency Coefficient & 0.213 & 0.818 \\
\hline
\end{tabular}

\section{Pembahasan}

Belajar adalah aktivitas secara sadar dalam usaha perubahan perilaku yang relatif permanen hasil dari interaksinya dengan lingkungan. Banyak cara yang digunakan orang untuk belajar, apalagi dalam era digital seperti sekarang ini. Dimana informasi tersaji dalam berbagai macam rupa. Tidak hanya itu saja, media untuk menyalurkan informasi tersebut pun sudah hadir dalam bentuk terkonvergensi, yaitu beberapa medium tergabung atau terintegrasi untuk digunakan dan diarahkan ke dalam satu titik tujuan (wikipedia). Hal ini pun akhirnya berimbas pada kebiasaan masyarakat digital dalam memproses informasi. Mereka lebih cepat memahami dengan menggunakan "one stop media" dan menjadi lebih mudah bosan saat informasi disajikan secara monoarah. Dengan adanya perubahan cara orang dalam memproses informasi tersebut, akhirnya ikut berpengaruh pula pada gaya mereka dalam belajar. Sekarang, pembelajar tidak lagi cenderung memiliki satu atau dua gaya belajar, namun menjadi multi gaya belajar atau multimodaliti. Implikasi lanjutannya, seorang pengajar harus mampu menghadirkan media yang dapat mengakomodir multimodaliti tadi. Dengan adanya media yang dapat mengakomodir multimodaliti, secara tidak langsung sudah mampu mengakomodir seluruh gaya belajar peserta didiknya. Hal ini sejalan dengan apa yang disampaikan oleh Alexandria City Public Schools “... often multiple modalities addresses different learning styles. Teachers using multiple modalities may use visuals, music, object, experience, collaborative work, ...". Tidak berbeda dengan itu, Ferriman (2013) pun menyatakan bahwa pembelajaran dengan menggunakan/mengakomodir multi gaya belajar akan membuat pembelajaran menjadi lebih efektif "Using an online learning approach that includes videos, reading, audio, exercises, social forums, and the like is a great way to hit on multiple learning styles. If you create learning for a living as an instructional designer or teacher, then blending your learning approaches is an effective way to make your learning stick".

Hal tersebut pun tergambar dalam hasil penelitian yang diketahui bahwa lebih dari separuh responden memiliki gaya belajar visual (64.3\%) dan hampir seluruh responden memiliki minat baca pada kategori rendah (56.3\%). Ini sesuai dengan hasil studi yang disampaikan Sebora (2008) dalam artikel jurnalnya bahwa kira-kira gaya belajar manusia lebih banyak visual (65\%), 30\% auditori, dan 5\% taktil/kinestetik. Namun demikian, pada dasarnya orang lebih banyak yang memiliki gaya belajar kombinasi atau gabungan dari beberapa gaya belajar yang ada. Ada penelitian yang menyatakan bahwa gaya belajar visual sesuai dengan era digital saat ini, dimana individu dengan gaya belajar seperti ini memiliki kelebihan seperti: 1) visual dapat lebih menempel pada memori jangka panjang; (2) dapat mengirimkan pesan secara cepat; (3) bahasa visual 
lebih komprehensif untuk dipahami dan lebih efisien dalam mensistesiskan sejumlah besar informasi baru; (4) dapat lebih cepat membangkitkan reaksi (contoh: secara emosional) dibandingkan kata-kata; (5) dapat lebih memotivasi pembelajar; dan (6) penting untuk diingat, saat menggunakan pesan visual harus menggunakan gambar yang sesuai karena bila tidak maka akan menimbulkan dampak negatif, seperti peserta didik bukannya mempelajari materi yang disampaikan namun malah mencari tahu mengapa gambar tersebut yang digunaka untuk menyampaikan pesan (Gutierrez, 2014).

Namun, terkait minat baca terkonfirmasi dalam penelitian ini. Dimana responden bisa dikatakan berada pada kategori pada minat baca rendah. Menurut UNESCO, minat baca masyarakat Indonesia sekitar 0.001 persen atau dalam seribu orang hanya ada satu yang memiliki minat baca. Sedangkan menurut data BPS 2006, menunjukkan bahwa tingkat minat baca masyarakat yang berusia di atas 15 tahun menunjukkan $55 \%$ lebih tertarik membaca koran, 29\% membaca majalah, $16 \%$ membaca buku cerita, dan $44 \%$ membaca buku pelajaran sekolah. Sementara jumlah masyarakat usia 15 hingga 59 tahun yang buta aksara sebanyak 5,9 juta atau 3,70 persen dari 81 juta orang (nas/ray, 2016). Hal tersebut tidak terkonfirmasi karena mahasiswa yang dikenal dengan kaum intelektual, mau tidak mau didorong untuk memiliki minat baca lebih dari orang kebanyakan. Mereka dituntut untuk hal tersebut karena segala perkuliahan ataupun tugas terkait dengan aktivitas membaca. Selain itu menurut Harris dan Sipay (dalam Hana, dkk, 2015) dapat diketahui bahwa yang mempengaruhi minat baca adalah sesuatu yang bersifat personal dan institusional. Adapun yang termasuk dalam sifat personal adalah intelegensi, usia, jenis kelamin, kemampuan membaca, sikap, dan kebutuhan psikologis. Sedangkan yang termasuk dalam faktor institusional adalah tersedianya bacaan yang sesuai, latar belakang status sosial ekonomi, kelompok etnis, pengaruh teman sebaya, orang tua, guru, televisi, dan film.

Hal tersebut pulalah salah satunya yang menjadikan tidak terujinya hipotesis, padahal berdasarkan hasil penelitian Elin Olsson pada tahun 2009 didapati bahwa ada hubungan yang sangat kuat antara gaya belajar dengan membaca. Namun begitu, hasil penelitian ini ternyata sejalan dengan hasil penelitian Santy Widya Pratiwi, Zainal Arifin, dan Dewi Novita yang menyatakan tidak terdapat hubungan antara gaya belajar dan membaca komprehensif mahasiswa semester 4 Pendidikan Bahasa Inggris FKIP UNTAN.

\section{PENUTUP}

\section{Kesimpulan}

Tidak terdapat hubungan antara minat baca dengan gaya belajar mahasiswa LPTK sebagai calon guru profesional di era digital.

\section{Saran}

(1) dengan "mengikuti" gaya belajar peserta didik diharapkan pembelajaran menjadi lebih efektif dan efisien; (2) selain itu perlu juga dihadirkan bentuk media yang dapat mengakomodir multimodal (berbagai gaya belajar) sekaligus dapat selaras dengan kebiasaan membaca masyarakat digital, salah satunya dengan penggunaan CD-interaktif. Dengan ini diharapkan dapat membantu membangun kebiasaan membaca secara masif; (3) pengajar sebagai salah faktor yang dapat mempengaruhi dalam peningkatan minat baca diharapkan dapat lebih menstimulus peserta didik dengan berbagai kegiatan yang melibatkan aktifitas membaca.

\section{DAFTAR PUSTAKA}

Alexandria City Public Schools. Multiple modalities. http://www.acpsk12.org/pl/acps-classroomsin-focus/multiple-modalities / (Diakses 24 November 2016)

Asra, A. \& Prasetyo, A. (2015). Pengambilan sampel dalam penelitian survei. Jakarta: RajaGrafindo Persada.

Azwar, S. (2010). Penyusunan skala psikologis. Yogyakarta: Pustaka Pelajar.

Ferdianto, R. (2016). Minat baca Indonesia, peringkat 60 dari 61 negara. http://mediaindonesia.com/ news/read/64231/minat-baca-indonesia-peringkat-60-dari-61-negara/2016-08-30\#sthash. jMG7cZz4.dpuf (Diakses pada 28 November 2016)

Ferriman, J. (2013). 7 Major learning styles - which one are you? https:/ / www.learndash.com/7-majorlearning-styles-which-one-is-you/ (Diakses 23 November 2016)

Gutierrez, K. (2014). Studies confirm the power of visuals in elearning. http://info.shiftelearning.com/ blog/bid/350326/Studies-Confirm-the-Powerof-Visuals-in-eLearning. (Diakses 29 November 2016)

Hana, dkk. (2015). Rendahnya minat baca di kalangan generasi muda: Penyebab, dampak, dan cara meningkatkannya. http://kayiskay.blogspot.co.id/ (Diakses 29 November 2016)

Hardianto, D. (2011). Studi tentang minat baca mahasiswa 
Fakultas Ilmu Pendidikan UNY. http:/ / staff.uny. ac.id/sites/default/files/Studi\%20Tentang\%20 Minat \%20Baca \%20Mahasiswa \% 20FIP\% 20 UNY_0.pdf (Diakses 10 Februari 2015)

Juangsih, J. (2015). Peran LPTK dalam menghasilkan guru yang profesional. http:// download.portalgaruda. org $/$ article.php? article $=344265 \&$ val $=6288 \&$ title=PERAN\%20LPTK\%20DALAM\%20MENGHASILKAN\%20GURU\%20YANG\%20PROFESIONAL. (Diakses 28 November 2016)

Nas, R. (2016). Survei UNESCO: Minat baca masyarakat Indonesia 0.001 persen". http://gobekasi. pojoksatu.id/2016/05/19/survei-unesco-minat-baca-masyarakat-indonesia-0001-persen/\#. (Diakses 29 November 2016)

Olsson, E. (2009). Learning styles and reading. https://www.diva-portal.org/smash/get/ diva2:292384/FULLTEXT01.pdf. (Diakses 30 April 2017)

Pashler, H., McDaniel, M., Rohrer, D. \& Bjork, R. (2009). "Learning styles: Concepts and evidence". A Journal of The Association for Psychological Science. Vol. 9, No. 3.

Pendit, P.L. (2013). Digital native, literasi informasi dan media digital - Sisi pandang kepustakawanan". http://repository.uksw.edu/jspui/ bitstream/123456789/4721/1/Putu\%20Laxman\%20P_Digital\%20Native, \%20Literasi Full\%20text.pdf. (Diakses 10 Februari 2015)
Pratiwi, S.W., Arifin, Z. \& Novita, D. (2012). “The correlation between learning style and students' reading comprhension". http://erepository.uonbi. ac.ke/bitstream/handle/11295/93142/Mutua_A \%20correlation \%20study $\% 20$ between $\% 20$ learning $\% 20$ styles $\% 20$ and $\% 20$ academic $\% 20$ achievement $\% 20$ among $\% 20$ secondary $\% 20$ school.pdf? sequence $=1 \&$ isAllowed $=y$. (Diakses 30 April 2017)

Riyanto, Y. (2001). Metodologi penelitian pendidikan. Surabaya: SIC.

Sebora, J. (2008). "What type of learner are you?". Herald Journal. http:/ / www.herald-journal. com/archives/2008/columns/js091508.html (Diakses 29 November 2016)

Siswati. (2010). Minat membaca pada mahasiswa (Studi deskriptifpada mahasiswa fakultas Psikologi UNDIP Semester I)". Diakses pada 29 November 2016, dari http://download.portalgaruda.org/article.php?article $=22046 \& v a l=1286$.

Sugiyono. (2007). Metode penelitian kuantitatif, kualitatif, dan $R$ \& D. Bandung: Alfabeta.

VARK learning styles: Visual, auditory, read/write, kinesthetic. http:/ / www.gardner-webb.edu/Assets/ gardnerwebb/academics/advising/files/varklearning-styles.pdf (Diakses 24 November 2016)

Wikipedia. Konvergensi media. https://id.wikipedia. org/wiki/Konvergensi_media (Diakses 26 November 2016) 